\title{
Grundtvig and the abolition of slavery
}

\author{
By K. E. Bugge
}

N. F. S. Grundtvig's international renown is mainly due to his pioneering work in the fields of adult education and Anglo-Saxon philology. Less familiar is his engagement in political life. During nearly 18 years he was an elected member of the Danish parliament, which was established in 1849. Prior to this activity he had for nine years been a member of a small committee working for the abolition of slavery in the Danish West Indian islands. The committee was established at the initiative of the British and Foreign Anti-Slavery Society. Grundtvig's engagement in this special activity has until recently been practically unknown. Before 1839 Grundtvig's attitude was characterized by both concurrence and rejection. He shared two commonly accepted views: (a) That the slaves on the Danish islands were treated in a milder way than in the colonies of other European powers, and (b) that the benign nature of Danish absolute monarchy would in its own good time solve all remaining problems. Alongside these views we find in Grundtvig's early writings a fervent criticism of the horrendous avarice that through the centuries had maintained the institution of slavery. In 1839 Grundtvig revises his views and becomes personally involved in the cause of abolition of slavery. The failures and final success of the committee are here described on the basis of Danish and British sources.

From 1672 and for almost 250 years, three small islands in the Caribbean were colonies of Denmark. In 1917 they were sold to the United States and are now called the US Virgin Islands. In the former Danish West Indian colonies the trading of slaves was forbidden by law as early as 1792 . Slavery as such, however, continued until its abolition in 1848. In the political process leading up to this decisive event several different factors were combined. Among these was the contribution of a small anti-slavery committee during the preceding years, 1839-48. This committee played a limited, but not insignificant role. Grundtvig was a member of the committee during all the years of its existence.

British and American commentators have now and then expressed their surprise at the relatively long interval between the abolition of the slave trade in 1792 and the total abolition of slavery in 1848. Two explanations have been suggested. First, that Denmark lacked a vociferous abolitionist movement comparable to the well organized, untiring and successful pressure groups in Britain and the United States. Second, that this may have to do with the Danish state-church 
system. In Denmark religious freedom was not introduced before the adoption of a democratic constitution in 1849. Until then independent religious and political movements were restricted within very narrow confines. No doubt there is some truth in such observations. Nevertheless, three other factors seem to be of greater importance.

The first is the elementary geographical factor of the enormous distance between Denmark and the West-Indian colonies. It was difficult to arouse and maintain public interest in prevailing conditions in these far-off islands. - The second factor is the Danish system of government at that time. In the years before 1849 , when a democratic constitution was adopted, there was in this country no parliamentary debate whatsoever. All necessary governmental discussion took place between the absolute monarch and his ministers and officials. - The third factor, the role of the press, must be understood in that context of absolute monarchy. Fearing the influence of revolutionary ideas, rigorous punishment was imposed by law on all who publicly criticized the government and the establishment as such.

In view of these factors, it should seem practically impossible that a public debate could take place. Surprisingly this was nevertheless the case - also regarding the abolition of slavery. This issue was discussed both in the press and in a new political institution. Up through the 1830 s the press periodically brought series of articles on the question of abolition. Of course these articles had to be very carefully edited in order not to antagonize the authorities. Just as important and perhaps even more so were the new Provincial Advisory Councils (Danish: "Rådgivende Stænderforsamlinger") inaugurated by royal decree in 1831 and functioning from 1835 until 1848. Four such assemblies were established, two in the duchies Schleswig and Holstein, and two in the kingdom proper convening in the cities Roskilde and Viborg. These assemblies, which were organized after the German model, aimed at appeasing and thus containing the accelerating liberal movement. During their approximately 13 years of activity the advisory councils attained an unexpected positive influence both on legislature and on the development of political consciousness.

It was against this background that George William Alexander, an emissary of the British and Foreign Anti-Slavery Society, in 1839 visited Copenhagen in order to promote the cause of abolition. A few years later, in 1843, after a second visit by Alexander, the committee was enlarged to include five members in all. Members of the first committee were C. N. David, professor of economy and liberal politician, Jean-Antoine Raffard, a minister at the French Reformed Church of Copenhagen, and N.F.S. Grundtvig. Of the two new 
members joining in 1843 by far the most influential was the professor of botany J.F. Schouw, like David a liberal politician. The fifth member was the young theologian D. G. Monrad, who later gained prominence as bishop and as prime minister.

By combining information provided by Danish and British sources it is now possible to obtain a sufficiently clear idea of how this contact developed in the following years. Letters and other materials pertaining to the activity of the committee are found in the archive of N. F. S. Grundtvig at the Royal Library, Copenhagen. Furthermore, the letters and extensive drafts written by professor J. F. Schouw, the chairman of the committee from 1843 and onwards, are available in his archive at Rigsarkivet, i.e. the Danish State Archive, Copenhagen. The British sources, which are even more plentiful, are found in the archive of The British and Foreign Anti-Slavery Society (in the following abbreviated BFASS) kept at Rhodes House Library, an institution affiliated with the Bodleian Library, Oxford. In this library three groups of relevant documents are available: (a) The Minute Books of the BFASS, (b) numerous files of correspondence, and (c) a complete set of the periodical published by the BFASS, The AntiSlavery Reporter. On the basis of these sources the development of the cooperation between the BFASS and its Danish counterpart may be closely studied from month to month, sometimes from day to day.

\section{A Danish antislavery-committee is founded}

Between mid-August and late September 1839, the treasurer of the BFASS, G. W. Alexander, did not only visit Copenhagen; as slavery also existed on the Swedish West Indian island Saint Barthélemy, his travels were rounded off by a visit to Stockholm. After Alexander's return to England, he delivered an extensive report to the board of the society. About the visit to Copenhagen the following is recorded in the Minute Books of the BFASS.

G. W. A. subsequently proceeded to Copenhagen, where he remained nearly two weeks. During this time G. W. A. did not see a large number of persons, but some individuals of high rank were among those with whom he had interviews and some possessing a literary reputation. 
Several persons were absent from Copenhagen at the time of G. W. A.'s visit, who might have been expected to co-operate in endeavours for the abolition of the Slave trade and Slavery among those to whom G. W. A. had a letter of introduction, Peter Browne, Secretary of the British Legation at Copenhagen and a Cousin to Lord Sligo.

G. W. A. was favoured with an audience by the Crown Prince of Denmark in which G. W. A. endeavoured to point out to him the duty, importance and necessity of abolishing Slavery in the Danish WestIndian Islands.

G. W. A. also forwarded to the Crown Prince some documents in the Slave trade and Slavery and among these the last printed Parliamentary Papers relative to Jamaica and Guinea, proving the advantages resulting from freedom in a portion of the West Indies

G. W. A. also had the pleasure of an interview with the Crown Princess, which will be adverted to further in the conclusion of this report. During G. W. A.'s stay at Copenhagen General Scholten, the Governor of the Danish West India Islands, arrived in the City, with whom in company with Professor David G. W. A. had a long interview (BFASS (a), 110-111) (...). ${ }^{1}$

A small Committee was formed before G. W. A. left Copenhagen to whom and to a person about to sail for St. Croix, a short address was delivered as at Hamburgh previously to the formation of the Committee. Among the best friends of the Cause of negro freedom, whom G. W. A. met in Copenhagen, were Pastor Grundvig (sic!), a Lutheran minister, Pastor Raffard of the French Church and Professor David, the last the editor of a newspaper. Both Pastor G. and Professor David gave G. W. A. ground to expect that they would bring the subjects, which had been brought under their notice, before the Public through the Press.

G. W. A. left a considerable number of Anti-Slavery Documents with the Committee at Copenhagen and has since corresponded with two members of the Committee.

While at Copenhagen G. W. A. wrote an address to the King, which he wished to have presented, but circumstances prevented him doing so. The Crown Princess, however, consented, on G. W. A. asking her to do so, to place it in the hands of the King (ibid., 114115).

The "circumstances", which prevented an audience with king Frederik VI, were the serious illness of the king. However, Alexander was fortunate having made personal contact with the heir to the throne, the later king Christian VIII, and with his wife, the later queen Caroline Amalie. Both were persons characterized by a wide cultural horizon. Furthermore, the latter was the initiator of several philanthropic activities, of which the best known are the charity schools (Danish: 
"Asylskoler") in Copenhagen. Additionally, the princess with "Pastor Raffard of the French Church" as her personal assistant distributed money, food and winter fuel to the poor and needy. It is, therefore, hardly a coincidence, that Raffard became a member of the antislavery committee. Through him Caroline Amalie had a possibility of following and in an unofficial way supporting this new initiative. Concerning the other two members of the committee it seems evident that Alexander and the board of the BFASS were primarily interested in their prowess in addressing the public.

A few more details concerning the establishment of the committee may be gleaned from the letters written by the persons involved. In a letter dated 5 September 1839 Alexander informs the secretary of the BFASS that he arrived the day before, i.e. on September the fourth. He adds that as early as the following day he was visited by professor David, who was evidently the first of Alexander's personal contacts, even though Grundtvig is the first mentioned in the report. This assumption is confirmed by a letter from David to Grundtvig. Under 5 September David writes [my translation]:

The bearer of this letter, Mr. Alexander, has been recommended to me from London. He belongs to the Anti-Slavery Society. Apart from enlightenment about conditions in our westindian colonies he seeks to be informed about a number of points concerning the religious and ethical condition of the Danish people. Such knowledge you will be much better qualified than I to convey to him. Permit me, therefore, to recommend him to you.

Cordially,

C. N. David (Fasc. 448.i.c.IV).

According to this letter, Alexander was "recommended" to David from London. The chosen formulation implies that David had not been personally acquainted with Alexander before they met in Copenhagen. Earlier in the year David had visited London but had not contacted the BFASS. Had he availed himself of this opportunity while in London, he would certainly have met Alexander already then. David must, therefore, have received the recommendation from a mutual acquaintance.

Immediately after Alexander's departure from Copenhagen, David contacted Grundtvig and Raffard in order to summon the committee to a meeting. At the meeting, which probably took place in October, the members requested Grundtvig to formulate a statement addressed to the public. His hitherto unpublished draft reads as follows [my translation]: 
Fellow citizens!

As the slave-trade daily increases in spite of England's struggle against it, a society has recently (April 1839) been founded in London having as its purpose by all legal and peaceful means to work for the abolition of slavery in all America and thus block up the fount of the cruel and in no degree less despicable trade in human beings, a trade which will continue, as long as a profitable slave-market exists.

This society (British and Foreign Anti-Slavery Society) has incited us to investigate, whether an auxiliary society with the same purpose could be established also in Denmark. We could not refuse to do this, especially because the land of our fathers has had the honour of taking the first step towards the abolition of the trade in negro slaves, even though that step has not quite has measured up to the expectations, it aroused. Soon half a century will have elapsed since that first step (1792). And even though the slaves on our west-indian islands usually are treated in a milder way than are the majority of others, then they are nevertheless not yet to a lesser degree slaves, than they were 47 years ago. In the British colonies only 30 years passed between the first step and the last, which was the release of the slaves at public expense.

Although we in no way are able unconditionally to praise the English procedure in this important matter, as it seems even so much aimed at the advantage of the slave owners as at that of the slaves. And though, furthermore, a similar procedure in poor Denmark would be impossible; nevertheless, as certainly many of our fellow citizens share our wish to see slavery terminated in a positive way as soon as possible also in our Danish islands, we hereby invite like-minded to a meeting in order to deliberate whether there is reason to expect that the establishment of a society could promote the attainment of this wish.

In conclusion we take the liberty to make the comment that whatever the result might be of a discussion of this matter, then the desire to discuss the issue is inseparable from our empathy in the fate of our unhappy fellow human beings, who are sold as commodities and are treated - be it harshly or in a lenient way - as domestic animals without marriage, without the joy of having children and without anything that naturally makes man conscious of his higher status and urges him on to an activity worthy thereof (Fasc. 448.i.c.VII).

This appeal was never published, and we have no record of later committee-meetings. Furthermore, it seems that the three members had forgotten to maintain their contact with the BFASS. A series of events, which may - at least to some extent - explain their reticence, is the death of king Frederik VI on 3 December 1839, his burial on 16 January 1840 and the crowning on 28 June of the new king, Christian VIII. In a country governed by an absolute monarch the death of a king 
is a crucial event with ramifications into all sectors of society and widespread worries concerning the state of affairs under a new king. A more practical explanation could be that although at least two of the committee-members were able to speak English, the writing of a letter in that language posed some difficulty. Whatever the explanation might be, the BFASS did not forget its Danish counterpart. In May 1840 Grundtvig received a letter, dated 13 April, from G. W. Alexander. In the rendering of this letter, the frequent abbreviations will be explained when necessary.

Esteemed friend,

A considerable period has elapsed since I had the pleasure of seeing thee \& some other friends of an oppressed race in Copenhagen. Subsequently I have addressed Pastor Röffard (sic!) \& Profr David but have not heard from either of them.

It will be a satisfaction to me to learn what is passing in Denmark or in the Danish West India islands, bearing upon the circumstances of the slaves in those distant isles. What appear to be the prospects of their being placed in possession of that liberty of which they have so long been unjustly deprived \& thus placed in circumstances incalculably more favourable to their advancement in intelligence, morals \& religion than their present degraded state?

I was very much interested in hearing recently that Joseph John Gurney, a minister of the Society of Friends \& a well known writer on religious subjects has recently visited St. Croix \& St. Thomas. He has since proceeded to Antigua from which island he writes giving a very pleasing and satisfactory account of the state of freedom \& suggesting to his sister Elsath [Elizabeth] Fry, who is now on the continent, the desirableness of extending her journey to Denmark for the purpose of exciting an interest in that country in the abolition of slavery.

I am not aware that it is at all probable that $\mathrm{E} F$ will adopt her Brother's suggestion. I am indeed informed by one that has been her companion in Holland that it is not in his opinion likely that she will visit Denmark.

I cannot but hope that there are Christians in Denmark \& that I am writing to one of the number who will not allow the continuance (of) a system, unjust in principle as well as cruel in practice \& fearfully injurious to morality \& religion among all classes wherever it prevails.

It has been my lot recently to visit France \& Holland in the hope of rendering some service to the cause of Abolition in those countries. Thou wilt find in the last no [number] of the Anti-Slavery Reporter which is forwarded to thee, some account of the proceedings of the Depn [Deputation], of which I formed a part to these countries. The most striking features in the system of slavery in the colonies of these kingdoms so far as they came under our notice in reading or by report was the proportion of births \& deaths to each other $\&$ the few 
instances in which the marriage tie exists. $(\ldots)^{2}$ May I ask thee to inform me what the little anti-slavery band formed during my stay at Copenhagen have done since $m y^{3}$ departure. Can the Friends of the Negro in Denmark appoint Delegates for the approaching conference in London. We expect not a very few from the United States \& some from the West Indies. -3 are at present named from Jamaica -. I trust that it will prove not only a deeply interesting occasion, but one which will prove productive under the divine blessing of highly beneficial results.

Be so kind as to communicate these lines or the substance of these to Profr David \& Pastor Röffard. Can you make some considerable increase to your comee [committee]? I met a gentleman of the name of Rördam at the Palace when at $\mathrm{C}$ [Copenhagen] who appeared to be a good man \& from this circumstance \& the little conversation I had with him, one who might be looked to as a helper in your good cause.

With kind regards to thyself \& each member of the comee [committee],

\section{I remain}

Thy sincere friend

Geo Wm Alexander (Fasc. 448.1.c.1).

Initially Alexander relates that he previously has written to Raffard and David but has received no reply. Alexander has obviously been unaware of the fact that Raffard did not wish to communicate in English, and David was at this juncture quite busy laying the foundation of a new political career. Whatever their reasons might have been, Alexander's concern is, of course, understandable. The following sections of the letter bring the interesting information that Elizabeth Fry, the famous Quaker philanthropist, had been encouraged by her brother, Joseph Gurney, to visit Denmark. Gurney was an ardent advocate of the abolition of slavery. His personal motive for offering his encouragement is, therefore, quite obvious. The trip to Denmark took place in the following year.

Alexander continues by informing Grundtvig of his recent travels in Holland and France. There he has learned that only rarely are the slaves able to enter into marriage and that such conditions are probably an effective cause of immorality and irreligiosity. At this point Alexander inserts a strong recommendation: That delegates from Denmark partake in the planned international anti-slavery conference due to take place during the summer. Clearly it was important for the BFASS to demonstrate that abolition of slavery is a worldwide concern.

In conclusion the Danish committee is encouraged to enlarge its membership. In that connection Alexander mentions that he by 
coincidence had met Peter Rørdam, and that this man had made a favourable impression on him. Rørdam, who was one of Grundtvig's most faithful younger followers, was at that time actively involved in the social and educational initiatives organized by princess Caroline Amalie. His appearing "at the Palace" is most likely to be understood in that context. When the anti-slavery committee was reconstructed in 1843, Rørdam had already for two years been the vicar of a country parish far from Copenhagen.

Neither Alexander's extensive letter nor a short communication of 29 January 1841 from J. H. Tredgold, secretary of the BFASS, received an answer from Grundtvig. In the late summer of 1841, however, he received a letter, which he under no circumstances could ignore.

\section{Elizabeth Fry visits Copenhagen}

From Caroline Amalie, who a year earlier had been crowned as queen, Grundtvig received a letter dated 19 August 1841. The queen informs Grundtvig that she is surprised that he had not reported himself back from summer holidays. Evidently she wanted to see him. It turned out that the queen wished Grundtvig to function as interpreter for Elizabeth Fry, who within a few days was due to arrive in Copenhagen. The background for this request was that Grundtvig mastered English fairly well. He had visited England three times. Furthermore, the secretary of the British legation, Mr. Peter Browne, his wife Katharine Browne and the British chaplain in Elsinore, the Rev. Nugent Wade, were Grundtvig's personal friends.

On the day after their arrival, on 23 August, Elizabeth Fry and her brother were received by the queen at her summer residence north of Copenhagen. It is notable that the aforementioned pastor Raffard of the French Reformed Church was present at this exclusive event. On that background it is not surprising that he, in a letter which Elizabeth Fry and her brother the following day wrote to Grundtvig, is referred to as "their friend Raffard". The letter, which is unsigned, has previously - with some minor errors - been printed in an edition of Grundtvig's letters; it is here quoted directly from the manuscript kept in his archive. It reads as follows: 


\section{Hotel Royal $8^{\text {th }}$ Month [Aug] 23th (sic!) 1841, \\ (Monday Evening)}

Elizabeth Fry \& J. J. Gurney present their respects to the Pastor Grundtvig \& finding from their friend Raffard that he [i.e. Grundtvig] is willing to accompany them to the prisons will be much obliged by his coming to this hotel at 11 o'clock tomorrow morning. They feel much indebted to Pastor Grundtvig for his kindness (Fasc. 448.11.b) ${ }^{4}$.

It is clear that Raffard has gained the confidence of the famous visitors. Addressing Grundtvig the wording is polite, but reserved. The reason for this is probably the not always unfounded mistrust, which members of Free Churches harboured against representatives of an established church. Detailed information about the days in Copenhagen are provided by Gurney in his memoirs, in biographies of Elizabeth Fry and in reports published in Danish newspapers. Grundtvig accompanied the visitors to two of the prisons in Copenhagen. In one instance Grundtvig spoke in Danish to the inmates. According to Gurney the speech impressed the British visitors, although they did not understand the language:

They [i.e. the prisoners] were also addressed by the celebrated pastor Grundtwig (sic!), a truly spiritual man, who seems to depend on a divine influence in his preaching. It was evident to us that the unction accompanied his words, though we could not understand them (Braithwaite 1854, 278).

For Elizabeth Fry and her brother the encounter with Grundtvig was evidently a notable experience, perhaps a little frightening, but nevertheless fascinating.

The agenda for the following days included a renewed visit to the royal summer residence. This time also the king was present. Joseph Gurney availed himself of the opportunity to obtain a private audience with His Majesty, during which he impressed upon the king the necessity of abolishing slavery in the Danish West Indian islands. Without going into details the king promised to take such a decision. The next day, at a well attended public meeting, Elizabeth Fry spoke on the exigency of prison reforms, and Joseph Gurney spoke on the abolition of slavery. On 30 August they left Denmark in order to return to England via Germany.

Until recently Grundtvig's reactions to the encounter with Elizabeth Fry have been known only from a short and much later comment from the year 1855, but a few years ago an extensive and contemporary statement was found, namely the manuscript used by Grundtvig at a public lecture which he delivered on 31 August 1841 at 
a meeting of the historical and cultural association Danske Samfund (Danish Society). The topic was Elizabeth Fry. That she had made a deep and positive impression on Grundtvig will be evident from the following lines of his manuscript [my translation]:

What made a profound and refreshing impression on me was in no way her particular ideas and views on eternal salvation, but her mild seriousness, earnestness and truthfulness in speech. It was by no means her partiality for prisons and their inmates, but the general love of humanity that radiated from her face and spread out to all those, she met, in short her noble human nature, totally unartificial, through a whole lifetime glowing for a widespread charitable activity, but to a rare degree developed by consciousness, reflection and confidence.

Now, by the sight of this both venerable and lovable woman to praise Quakerness, as though it fostered such excellent human beings, that is in our situation not easy. We are used to regard religion as something existing by itself, as having little or supposed to have nothing to do with life, with thought and action. May I in passing point out that Mrs. Fry even as much among the lady Quakers as among Christians in general is a rare exception. On the other hand everything in her is so closely fused together with her faith and worship that it is impossible to ignore this, when one wishes to understand her life and undertakings (Fasc. 364.II.60).

The question is now, whether the encounter with Elizabeth Fry positively influenced Grundtvig's involvement in the cause of abolition of slavery. That seems to be the case. Traces of such an influence are found in a manuscript from October 1841, where Grundtvig discusses the concept of human rights. In earlier writings he had demonstrated a rather negative stance on that subject because of the historical ties between the idea of human rights and the French revolution. Revising these earlier ideas, he now points out that human rights, which involve freedom from slavery, must be rooted in the concept of man's God-given nature.

More important than this marginal reference to the unrightfulness of slavery is that the encounter with Elizabeth Fry according to his speech from August 1841 for Grundtvig had underscored the close link between personal faith and charitable activity, between conviction and consequential action. This effect coincides in time with Grundtvig's gradually growing involvement in the practical charitable activities organized and sponsored by Queen Caroline Amalie. The inspiration from these two stalwart women has thus prepared Grundtvig for a renewed engagement in the anti-slavery cause a few years later. 


\section{The first political action 1843-44}

In the beginning of August $1843 \mathrm{G}$. W. Alexander once again set out for Copenhagen and Stockholm. This time he was accompanied by Benjamin Baron Wiffen, also a member of the Quaker community. Wiffen was an acute observer. His letters to the board of the BFASS contain a wealth of interesting details from this continental journey. Already on the 14 August the two emissaries can inform the BFASS of meetings with quite a number of key persons. Later in the month on their way to Stockholm by ship, Wiffen wrote a report relating their impressions from the visit to Copenhagen. It is symptomatic of Wiffen's thoroughness that he enclosed a list of the contacts made, 26 individuals in all. Among these we find two members of the antislavery committee, C. N. David and J. A. Raffard. The third member, Grundtvig, was in England and did not return before Alexander and Wiffen had left Denmark.

By far the most decisive of the 26 interviews conducted by the two emissaries was their meeting with professor Joachim Frederik Schouw. On Wiffen's list of names Schouw is introduced as "Professor of Botany. Editor of - " According to Wiffen's report the meeting with Schouw was no success:

Another editor, whom we saw, is Schow (sic!), professor of Botany (...) Not having considered the details of the system of slavery he is a fixed gradual Abolitionist and in other respects not so likely to yield himself to our object as the two former individuals [i.e. the professors David and Nathanson] (BFASS (b), Letters C 12/29) ${ }^{5}$

The meeting with Schouw has obviously been prompted by hearing about Schouw's spare time activity as editor of a weekly magazine. Furthermore, it is clear that the two emissaries have been disappointed by learning that Schouw was "a gradual Abolitionist", in other words that he did not believe in the possibility and desirability of an immediate abolition of slavery, but preferred a gradual termination of the system over a number of years. What they failed to register was the fact that Schouw, who had been president of both advisory councils in Roskilde and Viborg respectively, was one of the most influential politicians in the country. Furthermore, they underestimated the adeptness of Schouw's politically trained mind. He was a man attuned to the necessity of considering and reconsidering a stand. And he was able to make a quick decision. Already before Alexander and Wiffen had left Stockholm and returned to England, Schouw had initiated a political process aiming at the complete and earliest possible abolition of slavery in the Danish West Indian islands. 
The first step taken by Schouw was to contact the members of the anti-slavery committee. In a letter addressed to David, Grundtvig and Raffard, Schouw writes as follows [my translation]:

The article on the abolition of negro slavery written by the Englishman Alexander and published in Dansk Folkeblad [the magazine edited by Schouw] and my conversation with the author on this issue has caused me to reconsider the matter. I have arrived at the conclusion that something very well might be done apart from dealing with the matter in the press. -

However, before I take any step regarding this, it is a matter of course that I approach the three men, who during Alexander's previous visit here have promised to work for the cause, in order to invite them to a meeting, where the matter could be the subject of our common deliberation. In this deliberation I should like that also Dr. Monrad could take part. It was he that introduced Alexander to me, and he is much interested in the cause.

Copenhagen, $24^{\text {th }}$ of September 1843

Respectfully, Schouw (Schouw's archive)

Whereas Schouw before writing this letter probably had only been casually acquainted with Raffard, he knew the other persons mentioned very well indeed. The families of Grundtvig and Schouw had been close friends for more than twenty years. David had for over ten years been Schouw's ally in liberal politics. Dr. D. G. Monrad was a promising young theologian and orientalist. He had just entered into the political arena aligning himself on the liberal wing together with David and Schouw.

At the meeting, which took place on 4 October, the committee was reconstructed to include Schouw and Monrad, five members in all. The strategy decided upon was to present a petition to the king via the above named Advisory Council at Roskilde. David was an elected member of this assembly from 1840 to 1848 . Schouw had been its president during the period 1834-40 and had an expert knowledge of rules and procedures. Furthermore, he was well acquainted with the politicians and administrators involved.

The next forthcoming session of the advisory council was stipulated to the later half of the following year. On 24 October 1844 the new president, the liberal politician professor $H$. N. Clausen incidentally also a close personal friend of Schouw - announced the following petition [my translation]:

Professor David: Petition from himself, pastor Grundtvig, Dr. Monrad, pastor Raffard and professor Schouw concerning as soon as possible to implement the total discontinuation of the negro slavery in the Danish 
West Indian islands. Furthermore, the president announced that he had received from professor David, for distribution among the members of the council, copies of the booklet written by G. W. Alexander: On the Moral Obligation and Expediency of an Immediate and Complete Abolition of Slavery in the Danish West Indian Colonies (Stcendertidende 1844, col. 659).

A small committee of three members was appointed with the task of formulating a resolution. Delighted with the success up till now Schouw decided to inform the BFASS of this latest development. A fortnight later he received an extensive reply dated 12 November:

Dear Sir,

At a recent meeting of the Committee of the British \& Foreign AntiSlavery Society, the Committee was deeply impressed with the advantages likely to result for the cause of Emancipation from that measure being proposed $\&$ advocated - in the legislative assemblies of countries possessing Slave Colonies. If I am not mistaken, a meeting of the "states" was lately to assemble at Copenhagen, should it be in session, the Comee [Committee] will be glad to know what steps are taken by yourself \& other friends of the Slave resident at or now in Copenhagen, where the subject of the immediate $\&$ entire abolition of slavery in the Danish West India Colonies [is] brought under the notice of the States, and they [i.e. the committee] will also feel obliged by your giving them any information relative to the result of such proceedings. I believe that you will not consider it needful for me to make any apology for thus addressing you.

The Comee [Committee] feel that with the knowledge, which they possess of the dreadful evils inseparable from Slavery - a knowledge more particularly acquired during the struggle for the termination of that iniquitous system in the British colonies - they cannot do less than use their best efforts to promote the cause of Emancipation in every country implicated in the sanction of Slavery. In so doing, they disclaim any intention of interfering with polities or party considerations. They believe that the object for which they are associated is one which the wise and good of all political parties must alike desire to accomplish.

I may be permitted [the] further remark that the Committee are by their fundamental rules restricted in their endeavour to promote the object they have in view to means exclusively of a moral, religious and pacific character. In the energetic \& persevering use of such means by yourself \& other friends of the Slave in Denmark, the Comee [Committee] cherish the hope that the day is not distant, when you will rejoice in the abolition of Slavery in the British West India Islands, and when with Emancipation there shall be experienced in those interesting regions a state of happiness, prosperity \& intellectual \& 
moral improvement, which it would be vain to expect under the unjust, unpolitic [i.e. not judicious] \& debasing system of Slavery.

I am, Dear Sir,

Yours respectfully

John Scoble,

Secretary (Fasc. 448.23.c).

The letter from the BFASS raises some questions. The letter was sent to Grundtvig. Why not to Schouw, who was the chairman of the Danish committee, or why not to David, who efficiently had helped Alexander under his two visits to Copenhagen? The most likely explanation is that Scoble had replaced Tredgold as secretary. As every new secretary would do in a similar situation, he has consulted the archive and seen that the last letter had been sent by Tredgold to Grundtvig. He therefore found it safe to mail also his letter to pastor Grundtvig in Copenhagen.

As could be expected, the board has been "deeply impressed" by the news from Denmark. However, immediately after the board has expressed its great satisfaction, some uncertainty has arisen, cf. the words "if I am not mistaken". The uncertainty is evidently rooted in the translation of the Danish "Stænderforsamling" = an assembly representing the major sections of society. If the letter from Copenhagen has been written by Raffard, of whom we know from later letters that he has functioned as the secretary of the Danish committee, then he has written in French "l'assemblée des états". The word "état" has several meanings: (a) state, in the normal political sense of the word, as used in "a sovereign state", (b) social position or status, (c) a major socio-economic section of a society, (d) condition, as for example "The tools are in a bad state". No wonder that the board of the BFASS has been wondering what exactly is happening. Is it a local Danish affair, or is it an international conference? The board seems to have been inclined in the direction of the last possibility, cf. "countries" in the first paragraph and "every country" in the second. Be that as it may, the board harboured no uncertainty about which fundamental principles should govern important political initiatives as this. They must, of course, be "of a moral, religious and pacific character."

In a letter of 20 November Raffard on behalf of the Danish committee informed the BFASS about the positive reception of the petition at the meeting of 31 October. An article announcing the event in the Anti-Slavery Reporter clarifies that the petition was "presented to the provincial states". All uncertainty and doubt has now vanished! No wonder that the first of the following letters is written in a happy, 
optimistic mood. On 10 December 1844 Scoble on behalf of the BFASS sends the following letter to Raffard, his secretary-colleague in Copenhagen:

My Dear Sir,

I have the satisfaction of acknowledging your letter of $20^{\text {th }}$ ultimo, by which I am pleased to learn that a Committee has been formed at Copenhagen to promote the Emancipation of the Slaves in the Danish Colonies. Your Communication will shortly come under the notice of the Committee of the British \& Foreign Anti Slavery Society - to whom I am sure that it will also give much satisfaction.

I have communicated the contents to our esteemed friend Mr. G. W. Alexander, to whom it is very enjoyable that the names of the members of the committee are those Gentlemen, with whom he had the pleasure of becoming acquainted when at Copenhagen. I cannot doubt, but that your Petition to the Provincial States for the freedom of the slaves in the West India Colonies belonging to Denmark will be productive of much good, especially if it be followed up by other measures having the same tendency. The reception appears to have been as favourable as could in the first instance have been anticipated there being no opposition either by the Government, or the assembly to which it was addressed. I hope that the Committee which has been appointed to take the matter into consideration will do justice to the important subject entrusted to them. I wait with much interest an account of further proceedings in reference to the prayer of the Petition of the States, and shall be obliged by a translation, which you have promised to send.

Wishing you an entire and speedy success in your efforts on behalf of those who groan under an unrighteous bondage

I am, Dear Sir

Yours respectfully

John Scoble, Secretary (Schouw's archive)

The letter is addressed to "Monsieur le Pasteur Raffard, Copenhagen, Via Hamburgh". Raffard has clearly taken on the function as secretary of the Danish committee.

When the promised translation of the petition appeared in the AntiSlavery Reporter early in January 1845, a negative development of the case at the Advisory Council had already shattered the hopes and the optimism of the preceding two months. On 20 December, at one of the very last meetings of its 1844 session, the Advisory Council at Roskilde decided to reject the petition. The reason offered for the rejection was lack of sufficient information about the issue in question.

The rejection was of course disappointing especially for Schouw, who had taken the initiative. However, as an experienced politician he 
was aware of the fact that it was not always necessary to take no for an answer. In a letter to the members of the Danish anti-slavery committee he therefore suggested the following procedure in order to prepare the presentation of a renewed petition at the next coming session of the Advisory Council in 1846. Furthermore, he suggested that the BFASS be informed of the rejection and of the plans for the future. Additionally he intended to find out which information it was that the committee of the Council had not been able to obtain; he would ask the board of the BFASS to assist the Danish committee to procure updated information about the condition of the slaves in West India. Finally he and Monrad would do their best to feed the press with Danish and translated articles on the issue of abolition.

The notes, which Grundtvig has added to Schouw's circular of 1 January 1845 , are the most extensive among the comments written by the members of the committee [my translation]:

Of course I cannot object to informing the Anti-Slavery Society of the distressing fate of the petition. However, I cannot accept any mitigating formulations. It is my impression that the people in Roskilde have treated the matter - or more precisely left it not to be treated - with more than indifference. I should know the Englishmen very superficially, if they, in spite of all the comments that were added, would not feel as I that a debate, where the issue was defeated, was by far preferable to such a reference to a committee and such an unpunished rejection referring to a bland pretext.

Requesting Count Knuth ${ }^{6}$, who offered himself as spokesman for this peculiar rejection, to account for which information it was, that was lacking and not even worth mentioning, could be neither improper nor useless; under all circumstances it would demonstrate that we did not share the indifference (Schouw's archive).

On the basis of the comments from Grundtvig and the other members of the committee Schouw then wrote a report to the board of the BFASS. The report was translated into French by Raffard, signed and dated 15 April 1845. The text is here quoted from the somewhat tattered original in the archive of the BFASS:

Monsieur Scoble, Secrétaire de la Société contre 1'Esclavage

Monsieur

Vous connaissez la pétition que nous addressâmes en Octobre 1844 aux États Provinciaux assemblés à Roeskilde; vous savez aussi l'acceuil, que cette pétition y reçut. Le Comité, chargé d'en faire un rapport, était composé de l'Éveque Mynster, du Comte Knuth \& du Major Prætorius. Le second de ces Messieurs s'est exprimé comme suit dans l'avant dernière séance des États, le 20 Décembre: 
“Comme membre du Comité, auquel a été envoyée une proposition sur l'émancipation des nègres esclaves, $j$ 'observerai au nom de ce comité, qu'il n'a pu se procurer sur cette sujet les renseignements réputés néccessaires pour présenter un travail complet. Le Comité s'est donné beaucoup de peine pour se mettre au fait de l'état des choses \& obtenir divers éclairissements de la part d'hommes compétents. Mais on comprendra, sans doute aisément, que les membres du Comité n'ont pas par eux-mêmes une connaissance spéciale de l'état des choses de qu'... [unreadable]... leur a fallu combattre bien des difficultés. C'est ...[covered by tape] ...dans le Comité que cette question ... [covered by tape] ... ne pouvont livrer un travail, qui passât dans tous les rapports pour accomplir le tâche qui lui avait été confiée."

Bien que le résultat de notre tentative soit peu satisfiant, néanmois nous avons l'intention de renouveller la pétition dans la séance prochaine des États en 1846. En attendant nous nous efforçons d'un côte: d'entretenir l'interêt du public pour cette cause, dans la littérature périodique, l'autre d'acquérir les éclairissements qui pouvaient être utiles. Ces éclairissements ne sont faciles à obtenir, parce que la population dans nos îles se compose en plus grande partie d'étrangers et parce que les employés Danois dans cette petite colonie se décident difficilement à faire des communications sur cet objet. Aussi nous serait d'autant plus précieux de recevoir sur les esclaves \& leur situation aux Antilles Danoises les faits dont la société pourait être en état de nous procurer la connaissance.

Monsieur le Professeur David ne signe pas avec nous parce qu'il est momentanément absent.

Nous restons vos fidèles \& dévoués Associés

[signed] Grundtvig D. G. Monrad Raffard Schouw Copenhague 15 Avril 1845 (BFASS (b), Letters, C 21/97).

Ten days later the text of this letter was additionally published (in Danish) in the weekly magazine, which was edited by Schouw. This provoked count Knuth, the spokesman of the committee appointed by the Advisory Council, to enter into a discussion with Schouw in the following issues of the magazine. The discussion eventually focused on the question of economic compensation to the slave owners in the event of emancipation. In a comment to a draft circulated by Schouw, Grundtvig too expressed his opinion on this matter [my translation]:

Taking as a point of departure the undoubtedly valid presupposition, that it is neither the market- nor the auction price, which slave owners should receive in compensation, but it is the value of a certain manpower at almost equally favourable conditions as the present that the government will owe the planters, then it seems evident to me that even though one would or would not call the transformation of the 
slaves to peasants working as bonded labour ${ }^{7}$ a real liberation, then it would be a condition under which they were protected by the general laws, and they would with or without marriage be able to conduct a true human life, and that would be a considerable improvement of their circumstances. It would also ensure the planters that amount of manpower, without which any compensation short of the full value of the plantations would be considered unsatisfactory. Furthermore, I believe that the negroes in view of their lack of civilization and their well known disinclination for work will for the time being be unsuited for a more free condition. The example of Haiti, which is capable of producing more sugar than all the rest of the West Indies, but is incapable of producing what the island itself needs, seems to me to be an irrefutable proof (Schouw's archive).

Grundtvig is clearly of the opinion that the condition of bonded labour is to be preferred to slavery. In his argumentation some of the ideas put forth already in the draft from the autumn of 1839 ("without marriage...a true human life") are easily recognisable. - The final section, from "Furthermore" to the end, is subdivided into two sections. The first is a general observation focusing on the negroes' lack of civilization and disinclination for work. Such observations clearly reflect prejudices and negative elements in the image of Africa in nineteenth-century Europe. The second is an historical observation focusing on the example of Haiti. This is no coincidence. In the year 1845 the problems of Haiti were frequently recounted and discussed in Danish newspapers.

The discussion with Knuth eventually ebbed away. During the following months the members of the committee - and especially its chairman - kept themselves busy preparing the next presentation of a renewed petition.

\section{The second petition, 1846}

Among the preparatory initiatives the following seem to be the most important. During the year 1845-46 several articles on the issue of slavery were published in the magazine edited by Schouw. Moreover, the text of the new petition to be presented was circulated among the members of the committee and commented by them. Finally, a strategy was decided upon. It is very likely that Schouw has discussed the procedure with the president of the Council, Professor H. N. Clausen. Although a discussion on this matter between the two is not mentioned in the written sources, it is unthinkable that such an exchange has not taken place between Schouw and Clausen, who - as already pointed out - were close personal friends. The first step was under all 
circumstances to ensure that the Advisory Council at this session had plenty of time to discuss the issue. The petition was, therefore, handed in at the very beginning of the session in mid-July 1846.

Already at the second meeting of the Council the president announced that professor David on behalf of himself and several others had presented "a petition concerning the abolition of slavery in the Danish West Indian colonies." A week later the petition was officially presented to the Council and a committee of five members was appointed with the task of preparing the coming discussion and the final decision on the matter. Among the five we find count Knuth, the spokesman of the first council-committee in 1844. His appointment is surprising, as he a year earlier had publicly taken exception to some of Schouw's views on the issue. However, one might also see his appointment as a evidence of a subtle strategy: Preventing him from obstructing the process.

After a preliminary hearing the final discussion took place on 26 August. Immediately before the vote was taken, the president, professor H. N. Clausen, made a personal statement. He pointed out that the issue at hand was not a matter that concerned only a few, and in which some persons have a greater competence than others. On the contrary, it is a matter that concerns humanity as such, and in which every man may have his say [my translation]:

Under certain circumstances the contrast between day to day reality and the first principles of Christian right and justice, the primary demands to a Christian civilization, is so glaring, that it is unacceptable to anyone - unless he, if it is possible, turns his eyes away from that debasement of human nature, that offence against Christianity, that lie at the root of such conditions (Stcendertidende 1846, col. 1582).

After the president in this way had moved the issue from a narrow socio-economic to a general, ethical context, the Council voted in favour of the formulation proposed by the committee [my translation]:

That the Council will make the petition:

That His Majesty will present to the Council at its next session a draft proposal for a law, which is founded on thorough local investigations, and which entails the complete emancipation of the unfree on the Danish Westindian islands.

Passed with 37 votes against 19 (ibid. col. 1584).

A second proposal dealing with the compensation to be paid to the slave owners was defeated and thus postponed to future decision. The final formulation, which was presented to the king, includes not only 
an introductory delineation of the procedure followed but also, as a preamble, a slightly extended version of the above quoted statement of professor Clausen.

After having received the petition the government acted remarkably quickly. Already on 28 July 1847 king Christian VIII signed the following communication addressed to the governor of the Danish West Indian islands, General Peter v. Scholten [my translation]:

It is our royal will motivated by justice, humanity and concern for our West Indian colonies and by the planters' own interest that the right of disposal over the unfree, of which the owners for the time being are in possession, shall be terminated in such a way that this transition - in order that the interests of all concerned may be respected and the necessary preparation for transition be made - shall be implemented 12 years after the date of this our sovereign resolution and the present conditions until then continue.

Additionally it is our supreme will that children of the unfree, who are born after the date of this our sovereign resolution should from their birth be free but remain with their mother or parents under certain conditions on which we reserve ourselves the right to make a detailed sovereign resolution.

By informing you of the above, we furthermore instruct you to bring the content of this our sovereign communication to public knowledge in our West Indian colonies (Ny Collegial-Tidende 1847, col. 665-666).

In an immediately following resolution the governor is instructed to set up a commission with the task of formulating a proposal for the practical implementation of the royal decision. These resolutions were made known to the public in Denmark in early September. For Schouw and the other members of the Danish anti-slavery committee it must have been deeply satisfactory to read this resolution. Not only was the petition expressly mentioned at the introduction of the official announcement; the text of the resolution itself also referred to justice and humanity. These motives had since the founding of the antislavery committee been its guiding principles.

Less satisfactory was the fact that the membership of the committee almost a year earlier, in the autumn of 1846 , had been reduced to three. Monrad was unable to continue, because he in September 1846 had been appointed vicar of a parish far from Copenhagen. A few months later David too left the committee. He felt that he had been passed by, because a letter from the BFASS did not mention his name among those, to whom the letter was addressed. This negligence had quite obviously had no ill intent and was simply 
due to the fact that David because of his absence from Copenhagen had not been among the signatories of the committee's letter of 15 April 1845. Even though Grundtvig attempted to mediate, David's decision was final. His exit was indeed regrettable. David had from the very beginning unquestionably been one of the most active members of the committee. And the cooperation within the committee had until then in all other respects been excellent.

\section{The final phase, 1848}

The last of the letters kept in Schouw's archive date from February 1847. This does not, however, mean that the correspondence between the Danish anti-slavery committee and the BFASS was discontinued at that point. In its October issue the Anti-Slavery Reporter brings a letter informing the readers of the resolution of the Danish king concerning the abolition of slavery in the Danish West Indian colonies. In the following issue, dated 1 November 1847, a letter from Raffard to Scoble is mentioned. A translation of the two royal resolutions is published together with quotations from Raffard's accompanying letter, also in translation:

But before transcribing them [i.e. the resolutions] we deem it our duty to present to your estimable colleague, Mr. Alexander, our sincere and grateful thanks, for having given, during his visit to Copenhagen, such an impulse to our efforts. We shall ever consider him to be the prime mover in this great and good cause.

Such is, my dear Sir, the point at which we have now arrived. We shall not fail to let you know of our subsequent progress, as soon as possible. May God bless your efforts. We shall ever remain in our humble sphere, your most grateful and devoted fellow-labourer.

In the name of the Committee

Your humble servant,

Raffard, Pastor (Anti-Slavery Reporter 1847, col. 163).

When Raffard in this letter only mentions one visit of Alexander, and not two, he must be referring to the very first visit in 1839, when the Danish committee was founded. The sincere and elegantly formulated thanks addressed to Alexander could have indicated that the committee by now had been disbanded, but no! In the next following paragraph Raffard ensures the BFASS that he will keep the society informed "of our subsequent progress". Raffard kept his promise. In the issue of the Anti-Slavery Reporter dated 1 January 1848 it is announced that the resolution concerning the abolition of slavery on the Danish West Indian islands has now been brought to the notice of the public on 
those islands. In September of the same year the readers are informed of the dramatic and decisive event, which during the summer of 1848 had brought about a complete abolition of slavery in the Danish colonies. During the following year, 1848-49, the Anti-Slavery Reporter now and then brings short notices on the development in the islands, but not a word about the Danish committee. It must, therefore, be concluded that the correspondence has been terminated after a period of nine years.

The dramatic event referred to above was the governor Peter v. Scholten's proclamation of 3 July 1848. On the background of unrest among the slaves and the subsequent risk that a slave rebellion on the neighbouring islands should spread to the Danish colonies, the governor had proclaimed an immediate and complete abolition in the Danish West Indies. To a huge crowd gathered on the island of St. Croix he announced: "Now you are free! You are hereby emancipated!" The abolition of slavery in Danish West Indies was from then on a reality. A formal endorsement thereof was given on 22 September 1848 in a proclamation issued by the new king, Frederik VII, the former king, Christian VIII, having died in January.

Not only Raffard, but also Grundtvig and Schouw, were of course aware of these events. During the year of 1848 they had, however, been preoccupied by other matters. The attention of Grundtvig was understandably much absorbed by the fact that his two sons had enlisted as soldiers in the war against the insurgents in SchleswigHolstein. Schouw was immersed in politics. The death of king Christian VIII had given the liberals new hopes of disestablishing absolute monarchy. Schouw and H. N. Clausen were both heavily involved in this process, in which the liberal opposition finally succeeded, when Frederik VII accepted a democratic, parliamentary constitution. The Advisory Councils were dissolved, and a new national assembly elected with the task of preparing the adoption of a new constitution in 1849. Both Clausen and Schouw were elected members of this assembly, Schouw as its president.

For Grundtvig the year 1848 was laden not only with anxiety concerning the two sons, but also by a series of decisive events. In October 1847 the then king, Christian VIII, had given him his personal assurance that his great idea of a folk high school at Sorø would shortly become a reality. As late as at a meeting of Scandinavian academics in the middle of January, Grundtvig had spoken about this coming event as a certain reality. A week later, on 20 January 1848, Christian VIII died, and Grundtvig's hopes were shattered. As, however, the political situation developed during the following 
months, other spheres of activity opened up to him. Step by step Grundtvig became involved in the political process and decided that he too should stand for election to the constitutional assembly. In this aspiration he was successful, and he joined the assembly in early November.

In Grundtvig's published writings and papers, in his speeches and letters from 1848, not a word is found referring to the abolition of slavery in the Danish West Indian islands. And yet, in a short speech delivered in parliament on 14 December, we find one statement. A member by the name of $\mathrm{H}$. P. Hansen had questioned the government about the present economic conditions on the islands after what had happened during the summer. This question unavoidably led on to the issue of compensation to the former slave owners. In that context the right of ownership was mentioned. This provoked Grundtvig to deliver the following short statement [my translation]:

The reason why I at this moment call for the attention of the assembly is just that as I too belong to those, who have laboured here the little they were able to, for abolition of the enslavement of negroes in the Danish West Indian islands, I cannot but refute an assertion repeatedly made today, that it should be accepted that it is possible for one man to possess his fellow men with full right of property; against this I protest in my name, and in the name, I should think, of all friends of humanity (Rigsdagstidende 1848, col. 461-462).

In this statement especially three points are interesting: The introductory motivation, the content of the protest and its final perspective.

The motivation offered by Grundtvig for rising and taking the floor is that he was one of "those, who laboured here (i.e. in Denmark) the little they were able to" for the emancipation of the slaves. In this formulation Grundtvig does not, as he often does in other cases, refer to his own writings or to what may be learned from history. He refers to something, which he has done in cooperation with others. The phrase "those, who have laboured here etc." must first of all refer to the small Danish anti-slavery committee. He may also have the Advisory Council in mind and especially the contributions of David and Clausen. Last but not least he may be referring to the initiative of the BFASS and his meeting with G. W. Alexander. The limiting addition: "the little they were able to" is not necessarily an expression of humility. More likely, it is a realistic reference to the strict constraints, which were unavoidable in a society governed by absolute monarchy.

The protest itself is a statement of principle: That it is impossible for one human being to own another. That the acceptance of such 
ownership has earlier prevailed is, therefore, invalid as an argument in the present discussion. The statement is concluded by inserting the protest in a universal perspective. The protest is not put forward in Grundtvig's name alone, but also "in the name of all friends of humanity." The first part of the protest in Grundtvig's own name, must refer to his own personal conviction, his Christian faith. According to this faith man is created in the image of God, and therefore it is wrong to treat human beings as if they were merchandise. The addition "in the name of all friends of humanity" refers to an ethical foundation, which is broader based than a personal and specific religious conviction. As such it may refer to the idea of human rights, which were often debated in the late eighteenth century. It may also refer to Elizabeth Fry and "the general love of humanity that radiated from her face". Finally, it may refer to the speech delivered by H. N. Clausen to the members of the Advisory Council on 26 August 1846. In his support of the second petition Clausen had characterized slavery as a "debasement of human nature". In view of all these perspectives Grundtvig's statement from December 1848 stands out not only as a concentrated summary of his basic views, but also as a worthy conclusion of his involvement in the cause of the abolition of slavery.

\section{Conclusions}

1. As stated above in the introductory remarks, Grundtvig's attitude towards the abolition of slavery is in his early writings characterized by both concurrence and rejection. This wavering stance is in 1839 replaced by an active and positive involvement in the cause of abolition. The explanations for this notable change of attitude are mainly two: (a) Grundtvig's impressive readiness to self-revision, i.e. his willingness to change a point of view, whenever he is convinced that he had been wrong. (b) All through Grundtvig's long life he was deeply influenced by personal relations. Behind a surface of gruff inaccessibility he was fundamentally a dialogical person. What he saw, read and heard was attentively registered, and what he considered important was stored in his capacious memory for future use. Also in Grundtvig's change of attitude towards the abolition of slavery personal relations were of decisive importance. In 1839 it was his former pupil and new friend, Professor C. N. David, the courteous and knowledgeable emissary of the BFASS G. W. Alexander and also perhaps via J. A. Raffard the princess Caroline Amalie, who prompted Grundtvig to join the first anti-slavery committee and succeeded. In 
1843 it is Grundtvig's old and trusted friend, J. F. Schouw, who persuaded him to continue as a member of the enlarged committee.

2. The years $1839-48$ emerge as an interesting period, which has been somewhat neglected by Grundtvig-research. The 1830s have always been admired because of the great publications of that decennium: Grundtvig's Nordens Mythologi (Mythology of the North) (1832), Haandbog $i$ Verdens-Historien I-II (the World History) (1833-36), his pioneering educational writings (1836-39), his famous collection of hymns (1837) and his comprehensive historical lectures (1838). In recent years the period from 1848 and onwards, when Grundtvig became involved in national politics, has attracted increasing attention. But apart from Flemming Lundgreen-Nielsen's studies on Grundtvig's engagement in the activity of the Danish Society ("Danske Samfund"), an historical and cultural association, the period in between, 1839 to 1848 , has been neglected.

Nevertheless, the years 1839-48, which cover the years in which the Danish anti-slavery committee existed, can be seen as a period of preparation for Grundtvig's later political activity as member of parliament during the years 1848-66. In the anti-slavery committee he had the privilege of working together with two of the country's foremost politicians, J. F. Schouw and H. N. Clausen. From these he has learned the lesson: That cooperating in spite of personal and ideological differences is an important precondition for success. Furthermore, the involvement in the anti-slavery committee and the personal influence of Schouw and Clausen have inevitably been instrumental in bringing about yet another change of attitude in Grundtvig: That he, the staunch adherent of benevolent, enlightened, absolute monarchy, revised his standpoint and was convinced that democracy was the future.

3. Our knowledge of Grundtvig's attitude towards the free churches in England has now gained a new and somewhat broader foundation. Grundtvig has often spoken and written on the Anglican Church, and his attitude towards this church has been thoroughly studied, for example by Helge Grell and A. M. Allchin. About the free churches Grundtvig has only rarely expressed himself. In his letters he has now and then recorded his impressions from participation in the services of some of these churches. Moreover, from some members of free churches he has learned much about British culture and politics. However, during his visits to England Grundtvig had, as far as we know, no contact with the Quaker community. The reason is probably 
that he in his early years nourished some antipathy towards Quaker theology. Against this background it is noteworthy that the personal contact with G. W. Alexander and the BFASS quietly but efficiently paved the way for that revision of his view, which took place in connection with the personal encounter with Elizabeth Fry in 1841.

4. Finally, one may raise some questions concerning Grundtvig's motivation for involving himself in the cause of the abolition of slavery. How strong was this motivation, and do other kinds of motivation than the above mentioned personal influences also come into the picture? At first sight Grundtvig's involvement in the antislavery cause does not seem to be strongly motivated, as he mentions this engagement neither in his public writings and speeches nor in his private letters. What is even more surprising is that he never answered the letters sent to him from the BFASS. This negligence may be caused by a relatively expensive postage. More likely is that even though Grundtvig spoke better English than most Danes in those days, yet writing a letter in that language represented a huge hurdle, which only very seldom was overcome by him. The specialist on Grundtvig's knowledge of languages, Dr. Helge Toldberg, has pointed out, that even in a cause of which we know that Grundtvig was very much engaged, namely the project of editing Anglo-Saxon manuscripts, he only very reluctantly wrote to his contacts in England. And this tardiness of Grundtvig's in no small measure contributed to the failure of his ambition (Toldberg 1947, 303-304).

Other observations create a basis for a more positive conclusion. In the autumn of 1839 it is Grundtvig, who formulates a draft to an appeal to the public. When Schouw four years later invites Grundtvig to join the enlarged committee, then he declares himself ready, at once and "with pleasure". All through the years, in which the committee existed, Grundtvig faithfully took his share of the work. His comments on the letters circulated were, as evident from the quotations above, quite thorough. His motivation has, therefore, been much stronger than it immediately appears to be.

Apart from the personal influences mentioned above, Grundtvig must also have seen cooperation in the anti-slavery movement in the light of social ethics. His visits to England in the early $1830 \mathrm{~s}$ acquainted him with the idea of working "for the common good", an idea which was related to the philanthropic ideas of the late eighteenth century, and with which Grundtvig had been familiar since his youth. In the introduction to his book on Nordic mythology (1832) he underscores the desirability of the cooperation between all men 
irrespective of their background and personal convictions. In order that the necessary tasks of society may be taken care of, what is required is that they all have "a flash of spirit and a spark of truthfulness". The composition of the Danish anti-slavery committee illustrated exactly that point. In this cooperation we find five persons of very different backgrounds and convictions. Grundtvig himself was a Lutheran pastor, a historian, and a poet apart from his other interests. Schouw was a botanist, David was an economist, Monrad was a theologian and an orientalist. Raffard was a pastor of the French Reformed Church. Their most important partners in the cause working outside but in close contact with the committee were Professor H. N. Clausen, Grundtvig's former theological antagonist, and the Quaker emissary G. W. Alexander. Indeed a motley group, but all of them men possessing "a flash of spirit and a spark of truthfulness", all men of good will ready to work for justice and humanity.

However strong and of whatever kind Grundtvig's motivation may have been, we know that it was more than just sufficient. With quiet pride he introduced his statement of December 1848 by pointing out that he too had been among those, who here had contributed, the little they were able, to the abolition of the enslavement of negroes on the Danish West Indian islands.

\section{Abbreviations}

BFASS: British and Foreign Anti-Slavery Society's archive, Rhodes House Library, Oxford.

BFASS (a): Minutes Books of the BFASS, Oxford.

BFASS (b): Archive of the BFASS, Oxford.

BFASS (c): = BFASS, Anti-Slavery Reporter (1847), Oxford.

$B G$ I-II: Georg Christensen og Stener Grundtvig (eds) (1924-26), Breve fra og til N. F. S. Grundtvig (Letters from and to N. F. S. Grundtvig), 1807-72, vol. 1-2, Copenhagen.

Fasc.: Fascicle of manuscript paper in the Grundtvig Archive, Royal Library, Copenhagen.

\section{Select Bibliography}

\section{Unprinted sources}

The major part of the sources are found in the following three archives:

N. F. S. Grundtvig's archive, The Royal Library, Copenhagen

J. F. Schouw's archive, The National Archive, Copenhagen 
British and Foreign Anti-Slavery Society's archive, Rhodes House Library, Oxford.

To a lesser degree the following archives have been used:

J. F. Schouw, Private archive, The Royal Library, Copenhagen

J. C. E. Nicolet: Histoire de l'église française de Copenhague. Archive of the Reformed Church, The Regional Archive for Zeeland, Lolland-Falster and Bornholm, Copenhagen

Dictionary of Quaker Biography, Friends House Library, London

\section{Printed sources}

With the main emphasis on sources available in English or French: Alexander, G. W. (1842), Letters on the Slave-Trade and Emancipation, London.

Begtrup, Holger (ed.) (1904-09), Nik. Fred. Sev. Grundtvigs Udvalgte Skrifter (Grundtvig's Selected Writings), vol. 1-10, Copenhagen.

— (1924), N. F. S. Grundtvigs Vartov-prcedikener (Grundtvig's Vartov Sermons), Copenhagen.

Braithwaite, John Bevan (ed.) (1854), Memoirs of Joseph John Gurney, I-II, London.

Bugge, K. E. (2003), Grundtvig og slavesagen (Grundtvig and the Cause of Abolition), Aarhus.

Buxton, Thomas E. (1839), The African Slave Trade, 2nd edition, London.

Clausen, H. N. (1877), Optegnelser om mit Levneds og min Tids Historie (Notes on the History of my Life and Time), Copenhagen.

Clément, D. L (1870), Notice sur l'église réformée de Copenhague, Copenhague, Paris \& Strasbourg.

Christensen, Georg og Grundtvig, Stener (eds) (1924-26), Breve fra og til N. F. S. Grundtvig (Letters from and to N. F. S. Grundtvig), 1807-72, vol. 1-2, Copenhagen.

Fry, Elizabeth (1847), Memoirs of the Life of Elizabeth Fry with Extracts from her Journals and Letters, ed. by two of her daughters, vol. II, London.

Grundtvig, Svend (ed.) (1877), N. F. S. Grundtvig's Mands Minde (N. F. S. Grundtvig's Memoirs), Copenhagen.

Johnson, R. Brimley (1931), Elizabeth Fry's Journeys on the Continent 1840-1841, London.

Ny Collegial-Tidende for Danmark 1841-48 (official government journal). 
Rørdam, H. F. (ed.) (1891-92), Peter Rørdam: Blade af hans Levnedsbog og Brevvexling fra 1806 til 1844 (Life and Letters), vol. 1-2, Copenhagen.

Saint-Anthoine, Hippolyte de (No year), Institut d'Afrique. But et moyen d'action, Worcester College Library, Oxford.

Schouw, J. F. (1923), "Selvbiografi” (Autobiography), in Carl Christensen, Joachim Frederik Schouw, Copenhagen, 3-11.

Shillitoe, Thomas (1839), Journal of the life, labours and travels of Thomas Shillitoe in the service of the gospel of Jesus Christ, vols. 1-2, London.

Stcendertidende (1844-46), Tidende for Forhandlingerne ved Provinsialstcenderne for Sjcellands, Fyens og Lolland-Falsters Stifter samt for Island og Farøerne (Journal for the negotiations at the Provincial Advisory Councils in the Dioceses of Sjælland, Fyn, Lolland-Falster and for Iceland and the Faroe Islands).

Toldberg, Helge (1947), 'Grundtvig og de engelske antikvarer' (Grundtvig and the English Antiquarians), Orbis Litterarum, 258311.

Udtog af Forestillingen til Kongen, angaaende Negerhandelens Afskaffelse (Extract of petition to the King concerning the abolition of the trade in negroes), Minerva (periodical), April 1792.

\section{Studies}

Barclay, Oliver (2001), Thomas Fowell Buxton and the Liberation of Slaves, York.

Davis, Brian (1998), A Historical Guide to World Slavery, Oxford.

Ekman, Ernst (1976), "Sweden, the Slave Trade and Slavery, 17841847" in Minchinton and Emmer 1976, 221-231.

Eltis, David \& James Walvin (1981), The Abolition of the Atlantic Slave Trade, Wisconsin.

Fuglestad, Finn, Løtveit, Morten \& Eian, Anne Kathrine (1994), LatinAmerikas og Karibiens Historie (History of South America and the Carribbean), Oslo.

Green-Pedersen, Svend Erik (1976), "The History of the Danish Negro Slave Trade 1733-1807" in Minchinton and Emmer 1976, 214215.

Hornby, Ove (1980), Kolonierne $i$ Vestindien (The Colonies / i.e. Danish / in West-India), Copenhagen.

Jennings, Lawrence C. (2000), French Anti-Slavery. The Movement for the Abolition of Slavery in France, Cambridge. 
Loftin, Joseph Evans (1968), The Abolition of the Danish Atlantic Slave Trade, Louisiana.

Mannix, Daniel P. \& Malcolm Cowley (2002): Black Cargoes. A History of the Atlantic Slave Trade 1518-1865, Penguin UK.

Minchinton, E. \& Emmer, Pieter C. (eds) (1976), The Atlantic Slave Trade. New Approaches, Société Françaises d' Histoire d' OutreMer, Paris.

Pope-Hennessy, James (2000), Sins of the Fathers. The Atlantic Slave Trade 1441-1807, London.

Rawley, James (1981), The transatlantic slave trade, N.Y.

Temperley, Howard (1972), British antislavery 1833-1870, London.

Walvin, James (1983), Slavery and the Slave Trade, London.

- (1992), Slaves and slavery. The British colonial experience, Manchester.

(1996, 1997), Questioning Slavery, London \& New York.

- (2000), Making the Black Atlantic. Britain and the African Diaspora, London \& New York.

\section{Grundtvig and his time}

Allchin, A. M. (1997), N. F. S.Grundtvig. An Introduction to his Life and Work, Aarhus.

Allchin, A.M. et al. (eds) (1993), Heritage and Prophecy. Grundtvig and the English-Speaking World, Aarhus.

- (2000), Grundtvig in International Perspective, Aarhus.

Knudsen, Johannes (1955), Danish Rebel. The Life of N. F. S. Grundtvig, Philadelphia.

Lindhardt, P. G. (1951), Grundtvig. An Introduction, London.

Koch, Hal (1952), Grundtvig, Ohio.

Thodberg, Christian \& Thyssen, A. Pontoppidan (eds) (1983), Tradition and Renewal. Grundtvig's Vision of Man and People, Education and the Church, in Relation to World Issues Today, Copenhagen.

A full bibliography and additional references may be found in Bugge 2003

Notes

At this point app. two pages recounting Danish views on the abolition of slavery are omitted.

2 Here is omitted a section containing detailed statistical information on the rate of marriage among the slaves in West India. 
3 At this point a printed communication signed by William Allen, Chairman of the BFASS, is pasted into Alexander's letter. These 21 lines are dated 15 February 1840. Allen informs his readers of the coming international "Anti-Slavery Conference" commencing in London on 12 June. The purpose of the conference is to discuss how to obtain "the total and unconditional abolition of Slavery".

4 Previously published in $B G$ II, 339.

5 "Nathanson" must be M. L. Nathansen, author of several books on economy and for twenty years (1838-1858) editor of the daily newspaper Berlingske Tidende.

6 Count F. M. Knuth, member 1844-1847.

7 In Danish: Hoveri. 